\title{
Analysis of Variance in Vocabulary Learning Strategies Theory and Practice: A Case Study in Libya
}

\author{
Salma H M Khalifa (Corresponding author) \\ School of Education and Modern Languages, Universiti Utara Malaysia, Malaysia \\ E-mail:salmauum@yahoo.com \\ Ahmad Affendi Shabdin \\ School of Education and Modern Languages, Universiti Utara Malaysia, Malaysia \\ E-mail: affendi@uum.edu.my
}

Doi:10.7575/aiac.alls.v.7n.3p.220

URL: http://dx.doi.org/10.7575/aiac.alls.v.7n.3p.220
Received: 09/02/2016

Accepted: 04/04/2016

\begin{abstract}
The present study is an outcome of a concern for the teaching of English as a foreign language (EFL) in Libyan schools. Learning of a foreign language is invariably linked to learners building a good repertoire of vocabulary of the target language, which takes us to the theory and practice of imparting training in vocabulary learning strategies (VLSs) to learners. The researcher observed that there exists a divergence in theoretical knowledge of VLSs and practically training learners in using the strategies in EFL classes in Libyan schools. To empirically examine the situation, a survey was conducted with secondary school English teachers. The study discusses the results of the survey. The results show that teachers of English in secondary school in Libya are either not aware of various vocabulary learning strategies, or if they are, they do not impart training in all VLSs as they do not realize that to achieve good results in language learning, a judicious use of all VLSs is required. Though the study was conducted on a small scale, the results are highly encouraging.
\end{abstract}

Keywords: vocabulary learning strategies, vocabulary learning theory, teaching of vocabulary learning strategies

\section{Introduction}

1.1 Background

Vocabulary is the most important component of a language and, with regards to learning a foreign language, some scholars go to the extent of saying that even if foreign language learners fail to completely master the syntactical nuances of the target language but manage to build a fairly good repertoire of its vocabulary, they can speak the language very well. For instance, Scrivener (1994) opined that,

Vocabulary is a powerful carrier of meaning. Language learners, say English learners, do quite often manage to pull off communication in English by using the accumulative meaning of each single word. As an example, a learner gets across much of his message/meaning saying "Tomorrow. Come party. Friends come. Enjoy. Fun." though the essentials of grammar are missing here, but meaning is clear through the vocabulary alone. (1994: 228)

Scholars working in the areas of applied linguistics and the psychology of language learning identified some language learning strategies in the1960s. These strategies basically derived from learning strategies in general but emphasized to be slightly different from areas of applied linguistics, and language learning involved different psychological adjustments for learners, especially when it comes to learning a foreign language. Taking a cue from language learning strategies, vocabulary learning strategies were suggested, to be different from language learning strategies in scope. Since learning and retention of the shapes, sounds and meanings of new words and their recall in appropriate contexts were shown to be a bit different in terms of psychological activities from learning the syntax of the target language and thus needed a different set of strategies. It is true that learners use language / vocabulary learning strategies without being made aware of them or without being trained to use them, but training in strategies and their use can leave a better impact on foreign language learning bringing better results faster.

\subsection{The Problem}

In Libya English is taught as a foreign language (Altaieb, 2013). Teaching of English in Libyan schools has passed through many phases and little researches have been conducted on teachers' perceptions of this new English language curriculum in Libyan High Schools. They revealed that the teachers generally follow the traditional approach to teaching, focusing more on the teaching of grammar and using the mother tongue to explain the meanings of certain words in English. Teachers are not generally trained in language /vocabulary learning strategies. Therefore, Learners are commonly exposed to only a single strategy to learn new lexical items in English, namely, memory strategy. In a traditional set-up where English teaching hasn't yet caught up with the recent methodological trends form-focused 
instruction suggests learners to mug up English words with their Arabic equivalents as meanings. In addition the learners are not made aware of the better use of vocabulary learning strategies, and also, to use all the possible strategies for better results. For instance, in the present digital age learners can make a good use of their time spent on social media and internet and using the modern gadgets the young learners use all the time, provided they are trained in the strategies of learning the target language outside the classroom. In a traditional classroom set-up like Libya with a 'top down approach' where the learners expect everything to flow down from the teacher, the learners do not explore strategies to learn new vocabulary items outside the classroom unless they are made aware of such strategies.

\subsection{Hypothesis}

Keeping this point in view, the researcher to hypothesize that the teachers' belief in the theoretical formulations underlining the usefulness of VLSs for learners in learning, retention and recall of vocabulary of foreign language is at variance with the practical implementation of the same belief.

\subsection{Research Questions}

To test the hypothesis stated above, the researcher has framed the present study to answer the following two research questions:

1. Does a significant number of secondary school English teachers in Libya hold confirmatory beliefs about the usefulness of VLSs to their students?

2. Is a significant number of secondary school English teachers in Libya teaching the use of vocabulary learning strategies to learn new lexis to their students?

\subsection{Aims and Objectives}

The present study is aimed at measuring the attitude of secondary school English teachers in Libya towards the teaching of vocabulary learning strategies to their students in the class. The study is non-judgmental and its primary objective is to determine the extent of awareness of teachers in secondary schools in Libya towards VLSs and their significance in foreign language learning process.

\subsection{Scope of the Study}

The study was conducted only on a small scale, and therefore the results obtained from the study cannot be taken to represent any larger scenario of Libyan secondary school English teachers' attitude towards VLSs. The only conclusion that can be drawn from the outcomes is that the results indicate the need to further study on the subject on a larger scale

\section{Literature Review}

\subsection{Vocabulary Learning Strategies}

\subsubsection{Theory}

The area of research on VLSs as a field is not properly defined and many scholars believe that vocabulary learning strategies cannot be different from language learning strategies. In the confusion, several researchers have given definition of the field different, if not contradictory, from each other (Nation, 2001; Chamot, 2001; Dorneyei, 2002; Catalan, 2003; $\mathrm{Gu}, 2003)$. Nation (2001: 352) argues that vocabulary learning strategies are one part of language learning strategies which in turn are part of general learning strategies. However, Dornyei (2002) believes that VLSs are different as they involve not only memorizing, recalling, and reviewing, the strategies used in language learning in general, but also using vocabulary items. Takac (2008) also agrees with Dornyei when he says that VLSs are those strategies which are solely used for vocabulary learning tasks.

Hogben \& Lawson (1996) have investigated some of the procedures students use in situations where they attempt some deliberate acquisition of vocabulary. They opine that the learners must analyze the "to-be-acquired word-meaning complex" and then must establish a representation of this complex in memory. They support their hypothesis through Mayer (1992) and Wittrock's (1992) argument that "The more effectively the to-be-learned material is elaborated during acquisition, the more readily it will be recalled." Gu and Johnson (2006) studied the relationship between vocabulary learning strategies used by Chinese students learning English and their outcomes and found that participants variedd in the using of vocabulary learning strategies. Most scholars agree that the six language learning strategies charted out by Oxford (1990) and others are commonly used by learners to learn vocabulary as well, with individual learners leaning heavily towards one or two of them. Indeed, language learning theorists also place significant stress on foreign language learners developing autonomous vocabulary learning strategies (Rossini Favretti, Silver, Gasser \& Tamburini, 1994 (quoted in Lawson and Hogben, 1996); McCarthy, 1990; Nation, 1990; Oxford 1990).

\subsubsection{Teacher's Attitude and Practice}

Teachers' attitude towards VLSs and their significance in vocabulary learning can make a large positive or negative impact on the learning behaviour of learners. This has been proven through research (Xhaferi and Xhaferi, 2008; Alyssa De, 2007; Miressa, 2014; Lai, 2005; Borg, 2003; Rashidi \& Moghadam, 2014; Riley, 2009). Teachers' beliefs and attitude affect their motivation and can sometime lead to anxiety. But, certainly beliefs and attitudes are not fixed; they may change in course of time and with accumulation of knowledge. Barcelos \& Kalaja (2011) and Zhong (2014) assert that beliefs and attitudes are dynamic and may change over times. Teachers' attitude also impacts their teaching practices as claims byYu-Ling (2005) that,

Studies on teachers' beliefs and practices have suggested that the "13,000-hour apprenticeship of observation" in the classroom plays a significant role in teachers' underlying assumptions and beliefs in language learning, which then exerts considerable influence on their teaching practices. (p. 5) 
The present study is slightly different from all the previous studies in a number of ways. First, the proposed study investigates teachers' attitude towards the teaching of VLSs to their students. Second, the study is conducted keeping in view both the theory and practice of teaching VLSs to students, though it does not investigate any relationship between them. Third, the setting, participants and the scope of the present study are entirely different from other studies.

\section{Methodology}

The present study is primarily oriented towards measurement of attitude through numerical data. Measurement of attitude is a complex process as the subjects may not be clear about their feelings, and the measurement instrument may not accurately reflect the exact attitude. Therefore, enough care has been taken to minimize the complexities arising out of interpretive inaccuracies. Attitude is generally measured through survey questionnaires, which measure it through indicative statements marked over a scale. Thus, it involves a two-tiered measurement: numerical data collection, and interpretation of numbers as indicators of qualitative feelings. The present analysis also employs a combination of quantitative and qualitative research methodologies. The first stage of the research is purely quantitative, while the second stage - interpretation of numerical data and the data collected through interviews - is qualitative in form. Two different survey questionnaires have been used to collect numerical data, one to know the number of teachers who understand the usefulness of VLSs in learning English, and the other to know the number of teachers who actually instruct students in VLSs. This data is used to arrive at the conclusion whether there is variance - in theoretical knowledge and practice of English teachers - with reference to VLSs. For the second stage research, the obtained numerical data have been interpreted to check the viability of the research hypothesis. Interviews with teachers serve as scaffolding and opinionated confirmation/rejection of a belief.

\subsection{Data Collection}

\subsubsection{The Instruments of Data Collection}

The data for the study have been collected through two different instruments, as outlined below:

3.1.1.1 Survey questionnaires: Two different survey questionnaires have been used to collect data from the participants. The first questionnaire was meant to gather information on the confirmatory belief of English teachers in secondary schools in Libya in VLSs, that they understand that VLSs are very useful in learning English and that learners should be formally instructed in the use of VLSs. The second questionnaire was thematically linked to the first one and was used to know the number of teachers who practically implemented their belief in VLS theory. Both the survey questionnaires contained both positive direction as well as negative direction statements to avoid bias in data collection. Positive direction statements supported the research hypothesis whereas negative direction statements went against it. Thus, the data obtained through both the questionnaires reveal two types of figures (i) number of teachers who are in conformity with positive direction, and (ii) number of teachers who do not conform to the direction of the questionnaire.

The questionnaires were designed by the researcher herself as no ready-made or tested questionnaires suiting to the needs of the researcher were found in any of the previous studies. The first questionnaire comprised of 10 statements, out of which 2 statements had negative direction. There were 16 statements in the second questionnaire, and 4 statements were oriented negatively. Every statement comprised of five options. - 1. Strongly disagree, 2 . Disagree, 3. Neutral, 4. Agree, and 5. Strongly agree. The distribution of credit on attitude for a positive direction for questionnaire 1 was as follows:

$\begin{array}{lccccc}\text { Response: } & \text { Strongly disagree } & \text { Disagree } & \text { Neutral } & \text { Agree } & \text { Strongly agree } \\ \text { Credit: } & 1 & 2 & 3 & 4 & 5\end{array}$

Whereas, for a negative direction the credit allocation was reversed, i.e., 5, 4, 3, 2, 1 .

Also, for questionnaire 2, to supporting the research hypothesis, the credit scheme was reversed, i.e., it was 5, 4, 3, 2,1 .

The final format of the questionnaire was given to five teachers for a review and clarity check. Internal consistency of the questionnaires for validity and reliability was checked through calculating Cronbach's Alpha. To calculate Cronbach's Alpha, the following formula was used:

$$
\alpha=(\mathrm{k} /(\mathrm{k}-1)) \times(1-\Sigma \text { Var/Var })
$$

Where,

$\mathrm{k}=$ number of statements in the questionnaire

Var $=$ variance (population standard deviation) of obtained scores for each statement

$\Sigma$ Var $=$ sum of variance

Both the questionnaires are given in Appendix A

3.1.1.2 Structured interview: The second source of data collection was interview with teachers of English. The interview technique was used essentially for two reasons: (a) to receive reinforcement of teachers on their opinions collected through questionnaire, and (b) to allow teachers to freely express themselves on the research theme [VLSs in this case] and its significance to them. Merriam (1998) and Denscombe (2003) opine that interview technique provides an understanding of the interpersonal, social and cultural aspects of the subjects under study. It was hoped that it would offer more insight and better understanding of the significance of VLSs to teachers. Structured interview format was put to use in the study. This was done for easy aggregation of responses over a wider range of issues (Lindlof and Taylor, 2002). Also, to arrive at a conclusive average number of responses on particular issues, it was imperative to keep each 
interview format exactly similar and the questions presented in exactly the same order. This also helped minimize the context effect, that is, respondents may answer particular questions depending upon the preceding question. Attempts were made to keep them constant across all respondents (Kvale and Brinkman, 2008). The interview questions were not adopted from any other research study. The interview questions were given to the participants, and so, all the participants had the same questions. There were 8 questions in the interview to which the participating teachers wrote answers in the space provided. Expert advice was sought on the nature of the interview questions, and they were found valid, reliable and reasonable.

Enough care was taken to ensure that there was no clash of interest for teachers in answering the questionnaires and the interview questions. The privacy of participating teachers has been maintained throughout the research and all codes of ethics in objective research have been followed.

\subsubsection{Research Setting and the Participants}

The present research was conducted at a few selected Libyan schools. As mentioned above, in Libya English is taught as a foreign language. The participating teachers selected for the study were from secondary schools who have been teaching English for not less than 4 years. This was to make sure that the respondent teachers had a fairly good experience of teaching English and understood the significance of vocabulary in the teaching of English.

\subsubsection{Sampling}

Sampling was involved in the research study at two levels: sampling of the schools for study and sampling of the participating teachers. Libya follows a uniform education system in secondary schools, therefore, a random selection method was adopted to select the schools as well as the participating teachers from those schools. Thus, enough care was taken to eliminate any bias in sampling.

The sample size for pilot study was 10 teachers. This number was 25 percent of the final research respondents as for the final study the survey was conducted with 40 teachers, and the same 40 teachers were interviewed.

\section{Research Procedure}

The following steps were involved in completing the present study:

i. Both the questionnaires were piloted before the final study. The pilot study was conducted with 10 participants. The main purpose of the pilot study was to test the validity, reliability and clarity of the test instruments. Interview questions were also piloted to test the research protocol, logistics and feasibility of the interview procedure and clarity of interview questions.

ii. For the final study, the questionnaires were distributed to a randomly selected group of English teachers, picked up from several secondary schools in Libya. The teachers returned the filled-in questionnaire the next day. All the questionnaire were returned filled-in.

ii. The same group of teachers were contacted for a structured interview. The interview questions were the same for all the teachers and were given to the participating teachers in typewritten format. The respondents wrote their opinions in the space provided.

\section{Data Analysis}

The data collected through pilot study were scrutinized for validity, reliability and internal consistency of the test items. Validity is the exactitude of measurement in the data collection procedure, that it measures what it intends to measure (DeVellis, 1991). Reliability refers to internal consistency of items in the test measure. According to Creswell (2014), if we get the same results on repeated experimentation, the test instrument is reliable.

The teachers' questionnaires statements were checked several times to ensure reliability. The reliability check analysis was performed for both the questionnaires using Cronbach's Alpha calculations. DeVellis (1991) says that an Alpha equal to $0.70(\alpha \geq 0.70)$ indicates very good reliability of the questionnaire, but a commonly accepted norm is that an Alpha of 0.60 is also acceptable. The reliability and internal consistency [calculated using the formula given above: $\alpha=$

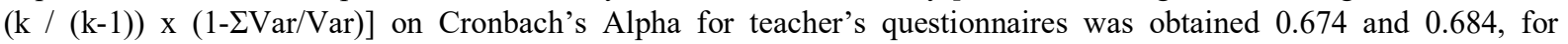
questionnaire 1 and 2 respectively, which are significant values. The results obtained for the questionnaires indicated the test instruments were reliable, the internal consistency of items was satisfactory, and thus the instruments were ready for final data collection. To ensure the validity of the attitude scale, expert opinion was sought. Further, the test results confirmed the validity of the instrument.

See Appendix B for detailed calculations.

\subsection{Results Obtained from the Data Collected through Questionnaires}

The data collected for the research study were analyzed to find out the exact figures for various indicators. Following are the results obtained through analysis of data for both the questionnaires.

Questionnaire 1: Table 1a given below shows the number and percentage figures of responses received for the five variables set in the questionnaire: Strongly agree-Agree-Neutral-Disagree-Strongly disagree. 
Table 1a. Questionnaire 1: Statement-wise Number/Percentage of Respondents

for All Five Variables - Strongly agree-Agree-Neutral-Disagree-Strongly disagree

\begin{tabular}{lllllllllll}
\hline A & B & C & D & E & F & G & H & I & J & K \\
\hline & Q1 & Q2 & Q3 & Q4 & Q5 & Q6 & Q7 & Q8 & Q9 & Q10 \\
\hline Strongly Agree & 16 & 0 & 20 & 20 & 0 & 16 & 20 & 8 & 0 & 20 \\
\hline$\%$ & 40 & 0 & 50 & 50 & 0 & 40 & 50 & 20 & 0 & 50 \\
\hline & & & & & & & & & & \\
\hline Agree & 24 & 0 & 12 & 20 & 0 & 16 & 16 & 24 & 0 & 20 \\
\hline$\%$ & 60 & 0 & 30 & 50 & 0 & 40 & 40 & 60 & 0 & 50 \\
\hline & & & & & & & & & & \\
\hline Neutral & 0 & 4 & 8 & 0 & 8 & 8 & 4 & 8 & 8 & 0 \\
\hline$\%$ & 0 & 10 & 20 & 0 & 20 & 20 & 10 & 20 & 20 & 0 \\
\hline & & & & & & & & & & \\
\hline Disagree & 0 & 12 & 0 & 0 & 8 & 0 & 0 & 0 & 4 & 0 \\
\hline$\%$ & 0 & 30 & 0 & 0 & 20 & 0 & 0 & 0 & 10 & 0 \\
\hline & & & & & & & & & & \\
\hline Strongly Disagree & 0 & 24 & 0 & 0 & 24 & 0 & 0 & 0 & 28 & 0 \\
\hline$\%$ & 0 & 60 & 0 & 0 & 60 & 0 & 0 & 0 & 70 & 0 \\
\hline & & & & & & & & \\
\hline
\end{tabular}

For convenience sake and for ease of understanding, the scores from Table 1a are simplified and presented in Table 1b, as given below.

Table 1b. Statement-wise Percentage for All Five Variables - Strongly agree-AgreeNeutral-Disagree-Strongly disagree

\begin{tabular}{lllllll}
\hline $\begin{array}{l}\text { Statement } \\
\text { No. }\end{array}$ & $\begin{array}{l}\text { Strongly } \\
\text { agree }\end{array}$ & Agree & Neutral & Disagree & $\begin{array}{l}\text { Strongly } \\
\text { disagree }\end{array}$ & Total \\
\hline & $\%$ & $\%$ & $\%$ & $\%$ & $\%$ & \\
1 & 40 & 60 & 0 & 0 & 0 & $100 \%$ \\
2 & 0 & 0 & 10 & 30 & 60 & $100 \%$ \\
3 & 50 & 30 & 20 & 0 & 0 & $100 \%$ \\
4 & 50 & 50 & 0 & 0 & 0 & $100 \%$ \\
5 & 0 & 0 & 20 & 20 & 60 & $100 \%$ \\
6 & 40 & 40 & 20 & 0 & 0 & $100 \%$ \\
7 & 50 & 40 & 10 & 0 & 0 & $100 \%$ \\
8 & 20 & 60 & 20 & 0 & 0 & $100 \%$ \\
9 & 0 & 0 & 20 & 10 & 70 & $100 \%$ \\
10 & 50 & 50 & 0 & 0 & 0 & $100 \%$ \\
\hline
\end{tabular}

The percentage figures of participants showing agreement to particular questionnaire statements were calculated by adding up the responses received for "Strongly agree" and "Agree." Similarly, to arrive at disagreement percentage figures, responses received for "Disagree" and "Strongly disagree" were added up. Responses received for "neutral" were left as it is. The figures thus arrived at are presented in light of the questionnaire statements to make better sense of the results, as given in Table 1c. 
Table 1c. Percentage of Respondents in Agreement or Disagreement with the Questionnaire Statements

\begin{tabular}{|c|c|c|c|c|c|c|}
\hline No. & & $\begin{array}{l}\text { Agreement } \\
\text { (Strongly } \\
\text { agree }+ \\
\text { Agree) }\end{array}$ & & Neutral & $\begin{array}{l}\text { Disagreement } \\
\text { (Disagree + } \\
\text { Strongly } \\
\text { disagree) }\end{array}$ & \\
\hline & & $\%$ & $\begin{array}{l}\text { Total } \\
\%\end{array}$ & $\%$ & $\%$ & $\begin{array}{l}\text { Total } \\
\%\end{array}$ \\
\hline 1. & $\begin{array}{l}\text { Vocabulary are very important elements of } \\
\text { teaching/learning English as a foreign language. }\end{array}$ & $40+60$ & 100 & 0 & 0 & 0 \\
\hline 2. & $\begin{array}{l}\text { All learners use some strategies to learn, retain and } \\
\text { recall the meanings of new words. }\end{array}$ & $0+0$ & 0 & 10 & $30+60$ & 90 \\
\hline 3. & $\begin{array}{l}\text { Generally, learners are not aware of various strategies } \\
\text { that may be put to use to learn new vocabulary items } \\
\text { in English. }\end{array}$ & $50+30$ & 80 & 20 & 0 & 0 \\
\hline 4. & $\begin{array}{l}\text { If learners know how to use vocabulary learning } \\
\text { strategies, they will become better vocabulary } \\
\text { learners. }\end{array}$ & $50+50$ & 100 & 0 & 0 & 0 \\
\hline 5. & $\begin{array}{l}\text { Vocabulary learning strategies use cannot be taught; it } \\
\text { is an inborn skill. }\end{array}$ & $0+0$ & 0 & 20 & $20+60$ & 80 \\
\hline 6. & $\begin{array}{l}\text { Students should be taught the use of vocabulary } \\
\text { learning strategies to help them learn vocabulary } \\
\text { faster and better. }\end{array}$ & $40+40$ & 80 & 20 & 0 & 0 \\
\hline 7. & $\begin{array}{l}\text { Without training in vocabulary learning strategies } \\
\text { learners may not put strategies to their best use to } \\
\text { learn new words. }\end{array}$ & $50+40$ & 90 & 10 & 0 & 0 \\
\hline 8. & $\begin{array}{l}\text { All vocabulary learning strategies are equally helpful } \\
\text { and effective in learning new vocabulary. }\end{array}$ & $20+60$ & 80 & 20 & 0 & 0 \\
\hline 9. & $\begin{array}{l}\text { Only some vocabulary learning strategies are good to } \\
\text { learn new words. }\end{array}$ & $0+0$ & 0 & 20 & $10+70$ & 80 \\
\hline 10. & $\begin{array}{l}\text { Teachers should encourage students to learn new } \\
\text { words from all possible sources outside the class. }\end{array}$ & $50+50$ & 100 & 0 & 0 & 0 \\
\hline
\end{tabular}

The responses received for "Neutral" were discarded since they neither show agreement to the statements nor disagreement. The results in Table 1c show the number and percentage of respondents displaying their agreement or disagreement to each questionnaire statement.

There were two types of statements in the research questionnaire: (i) statements with positive direction - in favour of the research hypothesis, and (ii) statements with negative direction - going against the research hypothesis. To arrive at the figure indicating the average number of respondents agreeing or disagreeing with the positive direction statements, mean of percentage of respondents agreeing or disagreeing with positive direction statements (all statements except 5 and 9) was calculated, as follows:

\section{Sum of percentage figures}

Mean of percentage $=$

Number of figures

$100+0+80+100+80+90+80+100$

Mean of percentage for agreement $=$

$=78.75$

In a similar manner, mean of percentage for (i) Disagreement for positive direction statements, (ii) Agreement for negative direction statements (statements 5 and 9), and (iii) Disagreement for negative direction statements was calculated. The results obtained are as follows:

(i) Mean of percentage for positive direction disagreement $\quad: 11.25$

(ii) Mean of percentage for negative direction agreement :00

(iii) Mean of percentage for negative direction disagreement $\quad: 80$ 
Analysis

The obtained results display that on an average 78.75 percent respondent teachers are in agreement with the positive direction statements. This means they confirm the researcher's belief that a majority of English teachers in Libyan secondary schools have a good understanding of VLSs. Only 11.25 percent of respondent teachers disagree with the positive direction indicating that they are either unaware of VLSs, or do not agree to the importance of VLSs in learning English. None of the participating teachers displayed agreement with negative direction statements, which is interpreted to mean that they assert their faith in VLSs, or, in other words, they realize the significance of VLSs. A very large number of teachers -80 percent display their disagreement with the negative direction statements, indicating that they do not support the denial of the role of VLSs in learning English.

Questionnaire 2: Table 2a given below shows the number and percentage figures of responses received for the five variables set in the questionnaire: Strongly agree-Agree-Neutral-Disagree-Strongly disagree.

Table 2a. Questionnaire 1: Statement-wise Number / Percentage of Respondents for All Five Variables - Strongly agree-Agree-Neutral-Disagree-Strongly disagree

\begin{tabular}{|c|c|c|c|c|c|c|c|c|c|c|c|c|c|c|c|c|}
\hline A & B & $\mathrm{C}$ & D & $\mathrm{E}$ & $\mathrm{F}$ & G & $\mathrm{H}$ & I & $\mathrm{J}$ & K & $\mathrm{L}$ & $\mathrm{M}$ & $\mathrm{N}$ & $\mathrm{O}$ & $\mathrm{P}$ & Q \\
\hline & Q1 & Q2 & Q3 & Q4 & Q5 & Q6 & Q7 & Q8 & Q9 & Q10 & Q11 & Q12 & Q13 & Q14 & Q15 & Q16 \\
\hline $\begin{array}{l}\text { Strongly } \\
\text { Agree }\end{array}$ & 16 & 0 & 20 & 0 & 0 & 0 & 0 & 8 & 0 & 20 & 0 & 16 & 20 & 8 & 20 & 0 \\
\hline$\%$ & 40 & 0 & 50 & 0 & 0 & 0 & 0 & 20 & 0 & 50 & 0 & 40 & 50 & 20 & 50 & 0 \\
\hline Agree & 24 & 0 & 12 & 0 & 0 & 0 & 0 & 24 & 0 & 20 & 0 & 16 & 16 & 24 & 16 & 0 \\
\hline$\%$ & 60 & 0 & 30 & 0 & 0 & 0 & 0 & 60 & 0 & 50 & 0 & 40 & 40 & 60 & 40 & 0 \\
\hline Neutral & 0 & 4 & 8 & 0 & 8 & 0 & 4 & 8 & 8 & 0 & 8 & 8 & 4 & 8 & 4 & 0 \\
\hline$\%$ & 0 & 10 & 20 & 0 & 20 & 0 & 10 & 20 & 20 & 0 & 20 & 20 & 10 & 20 & 10 & 0 \\
\hline Disagree & 0 & 12 & 0 & 24 & 8 & 16 & 20 & 0 & 4 & 0 & 8 & 0 & 0 & 0 & 0 & 16 \\
\hline$\%$ & 0 & 30 & 0 & 60 & 20 & 40 & 50 & 0 & 10 & 0 & 20 & 0 & 0 & 0 & 0 & 40 \\
\hline $\begin{array}{l}\text { Strongly } \\
\text { Disagree }\end{array}$ & 0 & 24 & 0 & 16 & 24 & 24 & 16 & 0 & 28 & 0 & 24 & 0 & 0 & 0 & 0 & 24 \\
\hline$\%$ & 0 & 60 & 0 & 40 & 60 & 60 & 40 & 0 & 70 & 0 & 60 & 0 & 0 & 0 & 0 & 60 \\
\hline
\end{tabular}

For convenience sake and for ease of understanding, the scores from Table $2 \mathrm{a}$ are simplified and presented in Table $2 \mathrm{~b}$, as given below.

Table 2b. Statement-wise Percentage for All Five Variables - Strongly agreeAgree-Neutral-Disagree-Strongly disagree

\begin{tabular}{lllllll}
\hline $\begin{array}{l}\text { Statement } \\
\text { No. }\end{array}$ & $\begin{array}{l}\text { Strongly } \\
\text { agree }\end{array}$ & Agree & Neutral & Disagree & $\begin{array}{l}\text { Strongly } \\
\text { disagree }\end{array}$ & Total \\
\hline & $\%$ & $\%$ & $\%$ & $\%$ & $\%$ & \\
1 & 40 & 60 & 0 & 0 & 0 & $100 \%$ \\
2 & 0 & 0 & 10 & 30 & 60 & $100 \%$ \\
3 & 50 & 30 & 20 & 0 & 0 & $100 \%$ \\
4 & 0 & 0 & 0 & 60 & 40 & $100 \%$ \\
5 & 0 & 0 & 20 & 20 & 60 & $100 \%$ \\
6 & 0 & 0 & 0 & 40 & 60 & $100 \%$ \\
7 & 0 & 0 & 10 & 50 & 40 & $100 \%$ \\
8 & 20 & 60 & 20 & 0 & 0 & $100 \%$ \\
9 & 0 & 0 & 20 & 10 & 70 & $100 \%$ \\
10 & 50 & 50 & 0 & 0 & 0 & $100 \%$ \\
11 & 0 & 0 & 20 & 20 & 60 & $100 \%$ \\
12 & 40 & 40 & 20 & 0 & 0 & $100 \%$ \\
13 & 50 & 40 & 10 & 0 & 0 & $100 \%$ \\
14 & 20 & 60 & 20 & 0 & 0 & $100 \%$ \\
15 & 50 & 40 & 10 & 0 & 0 & $100 \%$ \\
16 & 0 & 0 & 0 & 40 & 60 & $100 \%$ \\
\hline
\end{tabular}

As for questionnaire 1, the percentage figures of participants showing agreement to particular questionnaire statements were calculated by adding up the responses received for "Strongly agree" and "Agree," and to arrive at disagreement 
percentage figures, responses received for "Disagree" and "Strongly disagree" were added up. Responses received for "neutral" were left as it is. The figures thus arrived at are presented in light of the questionnaire statements to make better sense of the results, as given in Table 2c.

Table 2c. Percentage of Respondents in Agreement or Disagreement with the Questionnaire Statements

\begin{tabular}{|c|c|c|c|c|c|c|}
\hline \multirow[t]{2}{*}{ No. } & & \multicolumn{2}{|l|}{$\begin{array}{l}\text { Agreement } \\
\text { (Strongly } \\
\text { agree }+ \text { Agree) }\end{array}$} & \multirow[t]{2}{*}{ Neutral } & \multicolumn{2}{|l|}{$\begin{array}{l}\text { Disagreement } \\
\text { (Disagree }+ \\
\text { Strongly disagree) }\end{array}$} \\
\hline & & $\%$ & $\begin{array}{l}\text { Total } \\
\%\end{array}$ & & $\%$ & $\begin{array}{l}\text { Total } \\
\%\end{array}$ \\
\hline 1. & $\begin{array}{l}\text { I encourage my students to use memory strategies for } \\
\text { retention of word meanings through mental linkages. }\end{array}$ & $40+60$ & 100 & 0 & $0+0$ & 0 \\
\hline 2. & $\begin{array}{l}\text { I encourage my students to use cognitive strategies for } \\
\text { analysis of new word meanings. }\end{array}$ & $0+0$ & 0 & 10 & $30+60$ & 90 \\
\hline 3. & $\begin{array}{l}\text { I encourage my students to use determination strategies } \\
\text { for better recall of word meanings. }\end{array}$ & $50+30$ & 80 & 20 & $0+0$ & 0 \\
\hline 4. & $\begin{array}{l}\text { I encourage my students to use metacognitive } \\
\text { strategies to arrange and plan learning of new words. }\end{array}$ & $0+0$ & 0 & 0 & $60+40$ & 100 \\
\hline 5. & $\begin{array}{l}\text { I encourage my students to use affective strategies for } \\
\text { better control of their emotional states while learning } \\
\text { new words. }\end{array}$ & $0+0$ & 0 & 20 & $20+60$ & 80 \\
\hline 6. & $\begin{array}{l}\text { I encourage my students to use social strategies (asking } \\
\text { questions, etc.) for better understanding of word usage } \\
\text { in real life situations. }\end{array}$ & $0+0$ & 0 & 0 & $40+60$ & 100 \\
\hline 7. & $\begin{array}{l}\text { I encourage my students to use compensation strategies } \\
\text { for guessing and overcoming limitations in learning } \\
\text { new words. }\end{array}$ & $0+0$ & 0 & 10 & $50+40$ & 90 \\
\hline 8. & $\begin{array}{l}\text { I discourage my students from using social media, like, } \\
\text { Facebook. }\end{array}$ & $20+60$ & 80 & 20 & $0+0$ & 0 \\
\hline 9. & $\begin{array}{l}\text { I encourage my students to learn new words through } \\
\text { Internet sources, like online research sites and } \\
\text { vocabulary learning sites. }\end{array}$ & $0+0$ & 0 & 20 & $10+70$ & 80 \\
\hline 10. & $\begin{array}{l}\text { I encourage my students to learn new words using } \\
\text { thesaurus (hard copies as well as digital versions built } \\
\text { in some softwares, like MS Word). }\end{array}$ & $50+50$ & 100 & 0 & $0+0$ & 0 \\
\hline 11. & $\begin{array}{l}\text { I encourage my students to read English books to learn } \\
\text { new words outside the class. }\end{array}$ & $0+0$ & 0 & 20 & $20+60$ & 80 \\
\hline 12. & $\begin{array}{l}\text { I discourage my students from listening to English } \\
\text { songs at home. }\end{array}$ & $40+40$ & 80 & 20 & $0+0$ & 0 \\
\hline 13. & $\begin{array}{l}\text { I discourage my students from watching English } \\
\text { movies. }\end{array}$ & $50+40$ & 90 & 10 & $0+0$ & 0 \\
\hline 14. & I teach my students word formation rules. & $20+60$ & 80 & 20 & $0+0$ & 0 \\
\hline 15 . & I don't teach my students word maps. & $50+40$ & 90 & 10 & $0+0$ & 0 \\
\hline 16. & I teach my students word substitution games. & $0+0$ & 0 & 0 & $40+60$ & 100 \\
\hline
\end{tabular}

The responses received for "Neutral" were discarded. In questionnaire 2 also, there were two types of statements: (i) statements with positive direction - in favour of the research hypothesis, and (ii) statements with negative direction going against the research hypothesis. So, calculations for the data collected through the second questionnaire were similar to the calculations for the first questionnaire data, and were carried out to obtain the figures indicating the average number of respondents agreeing or disagreeing with both positive as well as negative direction statements. The following Means were calculated:

(i) Mean of percentage of respondents agreeing with positive direction statements (statement 8, 12, 13 and 15) $: 85$

(iv) Mean of percentage for positive direction disagreement $: 00$

(v) Mean of percentage for negative direction agreement (statements 1-7, 9-11,and 16) $: 30$

(vi) Mean of percentage for negative direction disagreement

Analysis

The important point to note in the questionnaire was that most of the statements included in it were directed negative to the research hypothesis, though at surface level they were positive statements, while the negative statements in the questionnaire took a positive direction. Accordingly, the available results show that on an average only 85 percent 
respondent teachers show their agreement to the positive direction statements. Again, they confirm the researcher's belief that a majority of teachers discourage their students from using alternate sources of learning new vocabulary in English, like, social media and the Internet. Teachers taking a stand negative to the research hypothesis are only 30 percent, which means only a small fraction of teachers encourage their students to make use of all VLSs. 60 percent of respondent teachers disagree with the negative direction, that is, they don't encourage students to use various VLSs.

\subsection{Interpretation of the Data Obtained through Questionnaires}

Survey questionnaire-1collected data on teachers' belief in the effectiveness of VLSs in learning English. The results obtained through analysis of the collected data indicate that the majority of English teachers in Libyan schools agree that teaching of vocabulary is the most significant element in teaching English as a foreign language in Libya. The agreement is interpreted as a fair awareness of Libyan teachers towards the theoretical underpinnings of vocabulary learning strategies.

Questionnaire-2 contained 16 statements, 12 of which were positive in format. But, since classroom practices of teachers differ from each other, the analysis of results need careful scrutiny. Statements 1-7 tested teachers' classroom practices, whether they encouraged their students to use various VLSs (memory, cognitive, determination, metacognitive, affective, social, and compensation strategies). A majority of teachers indicated that they do not formally encourage their students to use these strategies to learn new words, retain and recall their meanings in proper contexts. Statements number 8 relates to teachers' reactions towards the use of Internet social media to learn new English words, and again a vast majority of teachers discourage students from using such fads, like Facebook, even if they may help learn new words in English informally. It seems the practice hasn't gained popularity in Libya, and it is looked at with suspicion. Perhaps, the teachers feel that social media is not used by students to learn English language but only to make new friends. Statements 12, 13 and 15, were also negative in nature, and the results reveal that teachers discourage students from listening English songs and watching English films. Once again, it seems to be a cultural barrier, a reflection of the socio-cultural background of teachers. Libya is still quite a conservative country as regards cultural norms, and therefore, English songs are not much in favour there amongst the youth. The use of thesaurus, both print as well the digital format, is popular among teachers as they suggest their students the use of thesaurus. Teaching of vocabulary through word formation rules is not popular with teachers in Libya. And even smaller is the number of teachers who teach word maps and word substitution games to their students. This may be because teacher themselves may not be familiar with these techniques of teaching lexicon in the class.

\subsection{Analysis of the Data Obtained through Interview}

The respondents were interviewed using the following questions:

1. How long have you been teaching English as a foreign language?

2. Is vocabulary teaching a part of your everyday instruction?

3. Do you teach any new words in each class / every day?

4. How do you teach vocabulary to your students?

5. Do you suggest your students to learn English vocabulary outside the class too?

6. What sources of learning English vocabulary outside the class do you suggest your students?

7. Do you give students training in using strategies for learning vocabulary?

8. Do you notice any difference in their learning behaviour if you teach vocabulary learning strategies to your students?

9. Do you think teaching of vocabulary learning strategies be made an essential part of EFL curriculum in Libya?

10. Any other comments, suggestions or recommendations?

The respondents came with varying degrees of experience in the teaching of English, ranging from one and a half years to seventeen years. Almost all the teacher respondents said vocabulary teaching was a part of their everyday teaching instruction, and the similar number of participants said they taught new vocabulary items in each class, every day. This is to be interpreted that the majority of teachers in Libya believe vocabulary is a very significant element in learning English, and they take teaching of vocabulary very seriously. As regards the method of teaching vocabulary in their classes, the majority is using communicative approaches like, role play / writing new words with meaning / using pictures / using new words in sentences / providing hints to guess the meaning of new words / giving examples in context / giving difficult words to students to find their meanings at home / repetition / using cognitive strategies, authentic materials / explaining the meaning in various ways / giving synonyms /antonyms of new words / encouraging students to guess the meaning from the given context/ and self-study, etc.

But, a vast majority of teachers suggest that they do not formally teach or instruct their students in the use of VLS, for example, practices like, daily collection of new words and their meanings /finding common words of use / practicing language in situation /conversation in English with each other / watching English movies / listening to English music / watching programs in English on TV, like Discovery Channel, reading English magazines, books / reading English short stories, solving word puzzles / reading English newspapers, using internet sources, blogging / and interaction with native speakers, and so on. As it comes to giving training to students in using strategies for learning vocabulary, teachers said NO. Why? The reason may be that the teachers do not realize that students need formal training in VLSs. 
On being asked whether they noticed any difference in the learning behaviour of students if they taught vocabulary learning strategies to them, most teachers agreed their students did become better vocabulary learners. The vast majority of participants are in favour of teaching of vocabulary learning strategies be made an essential part of EFL curriculum in Libya. Only 4 teachers (10\%) disagreed with the proposal. This indicates that the teachers of English in Libya understand the significance of training their students in VLSs.

\section{Findings and Conclusion}

The present research study was designed to find answer to the following research questions:

1. Does a significant number of secondary school English teachers in Libya hold confirmatory beliefs about the usefulness of VLSs to their students?

2. Is a significant number of secondary school English teachers in Libya teaching the use of vocabulary learning strategies to learn new lexis to their students?

3. Is the beliefs of teachers in the usefulness of VLSs to their students at variance with practical implementation of the same belief?

Analysis of the data collected through questionnaires and structured interview reveals that the majority of teachers in Libyan secondary schools are aware of the theoretical formulations behind the advocacy of teaching vocabulary learning strategies to their students, and they express their confirmatory beliefs about the usefulness of VLSs in learning English.

But, in general, they don't formally teach their students any VLSs to learn new English lexical items, and specifically, they don't encourage students to use present-day multimedia resources, like, the Internet resources, English music and films, etc., resources that students can use to enhance their vocabulary out of classroom.

This anomaly brings us to the third question, and the hypothesis of the present study. The teachers' belief in the usefulness of VLSs is at variance with practical implementation of the same belief, or in other words, they do believe in the significance of VLSs for students and they do suggest ways to their students to learn new vocabulary items, but they don't practically impart students any training in VLSs. The teachers seem to encourage students only to use conventional strategies, i.e., memory and cognitive strategies. The unconventional strategies and modern-day digital technology-oriented ways of learning language haven't yet appealed to Libyan secondary school teachers. Maybe, teachers need to be more technology savvy, and environment needs to be built in Libyan schools in support of language learning using digital technology, Internet and social media.

\section{Suggestions for Further Research}

'Vocabulary Learning Strategies' is an interesting area of study, both in theory as well as practice. Scholars and researchers feel that VLSs should be taught to learners to enable self-directed learning among them. Keeping in view the individual pace, style, context and manner of learning, training in VLSs is highly advisable to be included in the foreign language classroom. The present research has been a small step in testing whether such an awareness is present among teachers of English in Libyan schools, and whether they translate this theoretical knowledge into practice or not. But, as mentioned above, the research was conducted at a very small scale, only with 40 participating teachers. It would be more encouraging if the attitude of teachers is measured at a larger scale, involving more schools.

Another aspect of the present research which I wished to explore but couldn't for lack of time and resources is the relationship between training of students in vocabulary learning strategies and the rate of their success in learning a new language, especially English. I observed that success in learning new language like English is somewhat linked to learners' awareness of various VLSs, i.e., the higher the awareness of VLSs, the more is the success achieved in learning the language faster. But, the idea needs further exploration through larger experiment/study.

\section{References}

Abdulgader, M. A., (2012). English Language Learning Strategies: A Survey of Their Praxis in the University of Sebha, Libya. The Indo-Libyan Linguist, 1.

Aljdee, A. (2011). The relationship between vocabulary learning strategies and vocabulary knowledge. The American University of Cairo, TESOL Journal. Special Issue.

Altaieb, S. (2013). Teachers' Perception of the English language Curriculum in Libyan Public Schools: An investigation and assessment of implementation process of English curriculum in Libyan public high schools. Electronic Theses and Dissertations. Paper 26

Amenu, M. (2014). An Assessment of the Practice of Vocabulary Teaching Strategies in EFL Classes: Kellem Secondary School Grade 9 And 10 English Teachers in Focus. Published MA thesis: Jimma University, Ethiopia.

Borg, S. (2003). Teacher Cognition in Language Teaching: A Review of Research on What Language Teachers Think, Know, Believe, and Do. Language Teaching, 36, 81-109.

Catalan, RMJ. (2003). Sex Differences in L2 Vocabulary Learning Strategies. International Journal of Applied Linguistics, 13, 54-77.

Chamot, A.U. (2001). The Role of earning Strategies in Second Language Acquisition. In, Breen, MP (Ed.), Learner Contributions to Language Learning: New Directions in Research. London: Longman. Pp. 25-43. 
Cohen, DA., and Dornyei, Z. (2002). Focus on the Language Learner: Motivation, Styles and Strategies. In, Schmitt, N (Ed.), An Introduction to Applied Linguistics. Oxford: OUP. Pp. 170-192.

Creswell, J. W. (2014). Research Design: Qualitative, Quantitative and Mixed Methods Approaches. Thousand Oaks: SAGE.

Denscombe, M. (2003). The Good Research Guide: For Small Scale Social Research Projects. Buckingham/Philadelphia: Open University Press.

DeVellis, R. F. (1991). Scale Development: Theory and Applications, $3^{\text {rd }}$ Edition. Thousand Oaks: SAGE.

Grady, M. P. (1998). Qualitative and Action Research: A Practitioner Handbook. Arlington, VA: Phi Delta Kappa Intl Inc.

Gu, PY. (2003). Fine Brush and Freehand. The Vocabulary-Learning Art of Two Successful Chinese EFL Learners. TESOL Quarterly, 37, 73-104.

$\mathrm{Gu}$, Y. and Robert K. (1996). Vocabulary Learning Strategies and Language Learning Outcomes. Language Learning, 46(4), 643-679.

Hogben, D. \& Lawson, M. J. (1996). The Vocabulary-Learning Strategies of Foreign Language Students. Language Learning, 46(1), 101-135.

Kvale, Steinar \& Svend Brinkmann. (2009). InterViews: Learning the Craft of Qualitative Interviewing, $2^{\text {nd }}$ Edition. Thousand Oaks: SAGE.

Lindolf, T. R., \& Bryan, C. T. (2002). Qualitative Communication Research Methods, $2^{\text {nd }}$ Edition. Thousand Oaks: SAGE.

Merriam, S. B. (1998). Qualitative Research and Case Study Applications in Education. San Francisco: Jossey-Bass.

Nation, I. S. (2001). Learning vocabulary in another language. Cambridge: Cambridge University Press.

Rashidi, N. and Moghadam, M. (2014). The Effects of Teachers' Beliefs and Sense of Self-efficacy on Iranian EFL Learners' Satisfaction and Academic Achievement. The Electronic Journal for English as a Second Language, 18(2), 123.

Riley, P. (2009). Shifts in Beliefs about Second Language Learning. RELC Journal, 40(1), 102-124.

Sawani, F. (2009). Factors affecting English teaching and its materials preparation in Libya. Unpublished PhD Thesis, University of Essex.

Scrivener, J. (1994). Learning teaching: A guidebook for English language teachers. Oxford: Macmillan Heinemann.

Siena, Alyssa De. (2007). Bridging the gap: Teachers' and students' perceptions of effective vocabulary instruction. Published Master's Thesis: Ralph Wilson School of Education.

Takac, VP. (2008). Vocabulary Learning Strategies and Foreign Language Acquisition. Clevedon, UK: Multilingual Matters.

Teijlingen, V., Edwin, R., and Vanora, H. (2016) The Importance of Pilot Studies. Social Research Update. Issue 35 (Winter 2001). University of Surrey, England. Sru.soc.surrey.ac.uk Accessed on 24.03.2016.

Xhaferi, B., and Gëzim, X. (2008). Vocabulary Learning Strategies Used by Students at Seeu in Terms of Gender and Teachers' Attitudes toward Teaching Vocabulary. Tetove: CIP - Katalogizacija vo publikacija Nacionalna i univerzitetska biblioteka "Sv. Kliment Ohridski", Shkup.

Yu-Ling, L. (2005). Teaching Vocabulary Learning Strategies: Awareness, Beliefs, and Practices. A Survey of Taiwanese EFL Senior High School Teachers. Published MA thesis: University of Essex.

\section{Appendix A: Questionnaires 1 and 2 \\ Consent Form \\ Dear participating teacher,}

Thank you for agreeing to participate in this research study.

My name is Salma. This research I am conducting is on teaching of vocabulary learning strategies to Libyan students. The title of the research is Analysis of Variance in Vocabulary Learning Strategies Theory and Practice: A Case Study in Libya. I would appreciate your participation in this project very much and I'd be happy to answer any further questions you may have about the project and its goals.

As a researcher, I am obliged towards the participants to make sure that there are no negative consequences from their participation in this study. The ethical principles that govern the present research are as follows:

\section{Code of ethics}

The participants' responses will remain strictly confidential.

Names of participants will not be disclosed anywhere in the study.

The data which I might use to report the findings of this research will remain anonymous. 
Participants will volunteer to take part in this study on their own accord, that is, participants are under no pressure to take part in the study and answer any question they may feel uncomfortable with.

\section{Consent:}

If you would like to take part in this research study, please sign below:

Signature: Date:

Name:

E-mail: Age:

School: Mobile:

\section{Questionnaire 1}

Please tick $[\sqrt{ }$ ] what to you is the most suitable choice for each of the following statements:

1. Vocabulary are very important elements of teaching/learning English as a foreign language.

$\begin{array}{lllllll}\text { Strongly } & & 2 & 3 & 4 & 5 & \begin{array}{l}\text { Strongly } \\ \text { Agree }\end{array}\end{array}$

2. All learners use some strategies to learn, retain and recall the meanings of new words.

$\begin{array}{lllllll}\text { Strongly } & & & & & & \text { Strongly } \\ \text { Disagree } & 1 & 2 & 3 & 4 & 5 & \text { Agree }\end{array}$

3. Generally, learners are not aware of various strategies that may be put to use to learn new vocabulary items in English.
Strongly
Disagree
1

2

3

$4 \quad 5$
Strongly
Agree

4. If learners know how to use vocabulary learning strategies, they will become better vocabulary learners.

$\begin{array}{lllllll}\text { Strongly } & & 2 & 3 & 4 & 5 & \begin{array}{l}\text { Strongly } \\ \text { Agree }\end{array}\end{array}$

5. Vocabulary learning strategies use cannot be taught; it is an inborn skill.

$\begin{array}{lllllll}\text { Strongly } & & 2 & 3 & 4 & 5 & \begin{array}{l}\text { Strongly } \\ \text { Agree }\end{array}\end{array}$

6. Students should be taught the use of vocabulary learning strategies to help them learn vocabulary faster and better.
Strongly
Disagree
2
34
Strongly
Agree

7. Without training in vocabulary learning strategies learners may not put strategies to their best use to learn new words.
Strongly
Disagree
12
3
$\begin{array}{lll}\text { Strongly } & \\ \text { Agree }\end{array}$

8. All vocabulary learning strategies are equally helpful and effective in learning new vocabulary.
Strongly
Disagree
Strongly

$3 \quad 4 \quad 5 \quad$ Agree

$\begin{array}{cc}1 & 2 \\ \text { earning } & \text { strategies }\end{array}$

9. Only some vocabulary learning strategies are good to learn new words.

$\begin{array}{lllllll}\text { Strongly } & & 2 & 3 & 4 & 5 & \begin{array}{l}\text { Strongly } \\ \text { Agree }\end{array}\end{array}$


10. Teachers should encourage students to learn new words from all possible sources outside the class.

$\begin{array}{lllllll}\begin{array}{l}\text { Strongly } \\ \text { Disagree }\end{array} & 1 & 2 & 3 & 4 & 5 & \begin{array}{l}\text { Strongly } \\ \text { Agree }\end{array}\end{array}$

Questionnaire 2

Please tick $[\sqrt{ }]$ what to you is the most suitable choice for each of the following statements:

1. I encourage my students to use memory strategies for retention of word meanings through mental linkages.

$\begin{array}{lllllll}\text { Strongly } & & & & & \text { Strongly } \\ \text { Disagree } & 1 & 2 & 3 & 4 & 5 & \text { Agree }\end{array}$

2. I encourage my students to use cognitive strategies for analysis of new word meanings.

$\begin{array}{lllllll}\text { Strongly } & & & & & \text { Strongly } \\ \text { Disagree } & 1 & 2 & 3 & 4 & 5 & \text { Agree }\end{array}$

3. I encourage my students to use determination strategies for better recall of word meanings.

$\begin{array}{lllllll}\text { Strongly } & & & & & \text { Strongly } \\ \text { Disagree } & 1 & 2 & 3 & 4 & 5 & \text { Agree }\end{array}$

4. I encourage my students to use metacognitive strategies to arrange and plan learning of new words.

$\begin{array}{lllllll}\text { Strongly } & & & & & \text { Strongly } \\ \text { Disagree } & 1 & 2 & 3 & 4 & 5 & \text { Agree }\end{array}$

5. I encourage my students to use affective strategies for better control of their emotional states while learning new words.
Strongly
Disagree

12
34
Strongly
Agree

6. I encourage my students to use social strategies (asking questions, etc.) for better understanding of word usage in real life situations.
Strongly
12

$3 \quad 4 \quad 5 \quad \begin{aligned} & \text { Strongly } \\ & \text { Agree }\end{aligned}$

7. I encourage my students to use compensation strategies for guessing and overcoming limitations in learning new words.

$\begin{array}{lllllll}\text { Strongly } & & 2 & 3 & 4 & 5 & \begin{array}{l}\text { Strongly } \\ \text { Agree }\end{array}\end{array}$

8. I discourage my students from using social media, like Facebook.

$\begin{array}{lllllll}\text { Strongly } & & 2 & 3 & 4 & 5 & \text { Strongly } \\ \text { Disagree } & 1 & 2 & 3 & \text { Agree }\end{array}$

9. I encourage my students to learn new words through Internet sources, like online research sites and vocabulary learning sites.
Strongly
Disagree
12

$34 \quad 5$ Agree


10. I encourage my students to learn new words using thesaurus (hard copies as well as digital versions built in some softwares, like MS Word).
Strongly
Disagree
123
$4 \quad 5 \quad$ Strongly

11. I encourage my students to read English books to learn new words outside the class.

$\begin{array}{lllllll}\text { Strongly } & & & & & & \text { Strongly } \\ \text { Disagree } & 1 & 2 & 3 & 4 & 5 & \text { Agree }\end{array}$

12. I discourage my students from listening to English songs.

$\begin{array}{lllllll}\text { Strongly } & & & & & & \text { Strongly } \\ \text { Disagree } & 1 & 2 & 3 & 4 & 5 & \text { Agree }\end{array}$

13. I discourage my students from watching English movies.

$\begin{array}{lllllll}\text { Strongly } & & 2 & 3 & 4 & 5 & \begin{array}{l}\text { Strongly } \\ \text { Agree }\end{array}\end{array}$

14. I teach my students word formation rules.

$\begin{array}{lllllll}\text { Strongly } & & & & & & \begin{array}{l}\text { Strongly } \\ \text { Disagree }\end{array} \\ \text { Agree }\end{array}$

15. I don't teach my students word maps.

$\begin{array}{lllllll}\text { Strongly } & & & & & \text { Strongly } \\ \text { Disagree } & 1 & 2 & 3 & 4 & 5 & \text { Agree }\end{array}$

16. I teach my students word substitution games.

$\begin{array}{lllllll}\text { Strongly } & & 2 & 3 & 4 & 5 & \begin{array}{l}\text { Strongly } \\ \text { Agree }\end{array} \\ \text { Disagree } & 1 & 2 & & & & \text { A }\end{array}$

\section{Appendix B: Calculation of Cronbach's Alpha}

Table 3. Scoring for Pilot Study: Mean, Standard Deviation, Variance, and Cronbach's Alpha for Questionnaire 1

\begin{tabular}{|c|c|c|c|c|c|c|c|c|c|c|c|c|}
\hline & A & $\mathrm{B}$ & $\mathrm{C}$ & $\mathrm{D}$ & $E$ & $\mathrm{~F}$ & $\mathrm{G}$ & $\mathrm{H}$ & $\mathrm{I}$ & $\mathrm{J}$ & $\mathrm{K}$ & $\mathrm{L}$ \\
\hline \multicolumn{13}{|l|}{1} \\
\hline \multicolumn{13}{|l|}{2} \\
\hline 3 & & Q1 & Q2 & Q3 & Q4 & Q5 & Q6 & Q7 & Q8 & Q9 & Q10 & Total \\
\hline 4 & 1 & 5 & 1 & 3 & 4 & 2 & 3 & 3 & 3 & 1 & 5 & 30 \\
\hline 5 & 2 & 5 & 2 & 5 & 4 & 1 & 4 & 4 & 3 & 1 & 4 & 33 \\
\hline 6 & 3 & 4 & 1 & 4 & 5 & 1 & 5 & 5 & 4 & 1 & 5 & 35 \\
\hline 7 & 4 & 5 & 2 & 5 & 5 & 3 & 3 & 4 & 5 & 3 & 4 & 39 \\
\hline 8 & 5 & 4 & 1 & 4 & 4 & 1 & 4 & 5 & 4 & 1 & 4 & 32 \\
\hline 9 & 6 & 4 & 2 & 5 & 5 & 2 & 5 & 4 & 4 & 1 & 5 & 37 \\
\hline 10 & 7 & 4 & 1 & 5 & 5 & 1 & 5 & 5 & 5 & 2 & 5 & 38 \\
\hline 11 & 8 & 5 & 1 & 3 & 5 & 1 & 5 & 4 & 4 & 1 & 4 & 33 \\
\hline 12 & 9 & 4 & 1 & 4 & 4 & 1 & 4 & 5 & 4 & 1 & 4 & 32 \\
\hline 13 & 10 & 4 & 3 & 5 & 4 & 3 & 4 & 5 & 4 & 3 & 5 & 40 \\
\hline \multicolumn{13}{|l|}{14} \\
\hline 15 & Mean & 4.3 & 15 & 4.3 & 4.6 & 1.6 & 4.1 & 4.6 & 4.2 & 1.4 & 4.6 & \\
\hline 16 & SD & .674 & .707 & .674 & .516 & .843 & .737 & .516 & .632 & .843 & .516 & \\
\hline 17 & Var. & .41 & .45 & .41 & .24 & .64 & .49 & .24 & .36 & .64 & .24 & \\
\hline \multicolumn{13}{|l|}{18} \\
\hline \multicolumn{13}{|l|}{19} \\
\hline 20 & $\mathrm{~K}$ & 10 & & & & & & & & & & \\
\hline 21 & $\Sigma$ var & 4.12 & & & & & & & & & & \\
\hline 22 & Var. & 10.49 & & & & & & & & & & \\
\hline 23 & $\alpha$ & 0.674 & & & & & & & & & & \\
\hline
\end{tabular}


Table 4. Scoring for Pilot Study: Mean, Standard Deviation, Variance, and Cronbach's Alpha for Questionnaire 2

\begin{tabular}{|c|c|c|c|c|c|c|c|c|c|c|c|c|c|c|c|c|c|c|}
\hline & $\mathrm{A}$ & $\mathrm{B}$ & $\mathrm{C}$ & $\mathrm{D}$ & $E$ & $\mathrm{~F}$ & $\mathrm{G}$ & $\mathrm{H}$ & I & $\mathrm{J}$ & $\mathrm{K}$ & $\mathrm{L}$ & $\mathrm{M}$ & $\mathrm{N}$ & $\mathrm{O}$ & $\mathrm{P}$ & $\mathrm{Q}$ & $\mathrm{R}$ \\
\hline \multicolumn{19}{|l|}{1} \\
\hline 2 & & & & & & & & & $\mathrm{~N}$ & & & & $\mathrm{~N}$ & $\mathrm{~N}$ & & $\mathrm{~N}$ & & \\
\hline 3 & & Q1 & Q2 & Q3 & Q4 & Q5 & Q6 & Q7 & Q8 & Q9 & Q10 & Q 11 & Q12 & Q13 & Q14 & Q15 & Q16 & Total \\
\hline 4 & 1 & 5 & 1 & 3 & 2 & 2 & 1 & 1 & 3 & 1 & 5 & 2 & 3 & 3 & 3 & 4 & 1 & 40 \\
\hline 5 & 2 & 5 & 2 & 5 & 1 & 1 & 2 & 2 & 3 & 1 & 4 & 1 & 4 & 4 & 3 & 5 & 2 & 45 \\
\hline 6 & 3 & 4 & 1 & 4 & 2 & 1 & 2 & 2 & 4 & 1 & 5 & 1 & 5 & 5 & 4 & 4 & 2 & 47 \\
\hline 7 & 4 & 5 & 2 & 5 & 2 & 3 & 1 & 2 & 5 & 3 & 4 & 3 & 3 & 4 & 5 & 4 & 1 & 52 \\
\hline 8 & 5 & 4 & 1 & 4 & 2 & 1 & 1 & 2 & 4 & 1 & 4 & 1 & 4 & 5 & 4 & 5 & 1 & 44 \\
\hline 9 & 6 & 4 & 2 & 5 & 1 & 2 & 1 & 3 & 4 & 1 & 5 & 2 & 5 & 4 & 4 & 5 & 1 & 49 \\
\hline 10 & 7 & 4 & 1 & 5 & 1 & 1 & 2 & 1 & 5 & 2 & 5 & 1 & 5 & 5 & 5 & 3 & 2 & 48 \\
\hline 11 & 8 & 5 & 1 & 3 & 2 & 1 & 1 & 1 & 4 & 1 & 4 & 1 & 5 & 4 & 4 & 5 & 1 & 43 \\
\hline 12 & 9 & 4 & 1 & 4 & 2 & 1 & 1 & 1 & 4 & 1 & 4 & 1 & 4 & 5 & 4 & 4 & 1 & 42 \\
\hline 13 & 10 & 4 & 3 & 5 & 1 & 3 & 2 & 2 & 4 & 3 & 5 & 3 & 4 & 5 & 4 & 5 & 2 & 55 \\
\hline \multicolumn{19}{|l|}{14} \\
\hline 15 & Mean & 4.3 & 1.5 & 4.3 & 1.7 & 1.6 & 1.6 & 1.8 & 4.2 & 1.4 & 4.6 & 1.6 & 4.1 & 4.6 & 4.2 & 4.4 & 1.6 & \\
\hline 16 & SD & .674 & .707 & .674 & .674 & .843 & 699 & .632 & .632 & .843 & .516 & .843 & .737 & .516 & .632 & 699 & .699 & \\
\hline 17 & Var. & .41 & .45 & .41 & .41 & .64 & .44 & .36 & .36 & .64 & .24 & .64 & .49 & .24 & .36 & .44 & .44 & \\
\hline \multicolumn{19}{|l|}{18} \\
\hline \multicolumn{19}{|l|}{19} \\
\hline 20 & K & 16 & & & & & & & & & & & & & & & & \\
\hline 21 & $\Sigma$ var & 6.97 & & & & & & & & & & & & & & & & \\
\hline 22 & Var. & 19.45 & & & & & & & & & & & & & & & & \\
\hline 23 & $\alpha$ & 0.684 & & & & & & & & & & & & & & & & \\
\hline
\end{tabular}

